\title{
Culture and Its Role in Promoting Democracy and Good Governance in Africa: Finding the Missing Link
}

IGBOKWE-IBETO, C. Justine | EWUIM, Ngozi | AGBODIKE, Florence

\section{Abstract}

$T_{\text {in }}^{\text {h }}$ pe paper examines the role of culture in promoting democracy and good governance in Africa. It also explores the concepts surrounding an optimal governance arrangement for cultural and democratic institutions and the challenges current arrangements have on organizational governance and structures to deliver optimal and effective outcomes. The paper argues that for culture to promote democracy and good governance, actions should be taken towards cultural re-orientation with the aim of making it useful to our democracy and governance. The emphasis on humanity and personhood finds expression in several African maxims.
Regrettably, the culture of individualism and primitive accumulation of wealth have dislocated humanity and personhood in Africa. We therefore, recommend among others, that communalism, high moral order in governance, community and state relations based on duties and obligations of the people to the state, deep sense of hard work and self-reliant, even as they embrace best practices from outside the continent of Africa. With these and other steps if implemented will launch the continent on the path of democratization and good governance by retrieving and showcasing its uniqueness as a people with deep sense of history and pride.

Keywords: Culture, Democracy, Good Governance, Service Delivery, Sustainable Development 


\section{Introduction}

Culture, democracy and good governance have organic relationship that if fully explored and internalized in the political and socio-economic life of the people of Africa could lead to the elusive peace, stability and development of the continent (Igbokwe-Ibeto \& Akhakpe, 2012:236). They went further to argue that for good measure, these elements have been brought to the forefront of debate on the ways forward for a continent plagued by incessant crisis of political violence, waste and corruption, underdevelopment and ravaging poverty, among other malaise.

Communitarian nature where people are their brothers' keeper and high moral order conditioned service to the people in pre-colonial Africa before the Western individualism came to be. Today, culture, democracy and good governance have become widely recognized as basic perquisites for sustainable socio-economic and political development around the globe. This imperative becomes urgent, following the failure of previous prescriptions from the West to turn the continent's fortunes around. For many scholars, (Onimode, 2007; Mandani, 2002; and Basil, 1992) going back to where we stopped with necessary adaptation to the experiences of the present may be the way out of the continent's bad government.

To this end, the communitarian nature of the people and the moral order that condition service to the people in pre-colonial Africa are fundamental bases on which the continent's governments could predicated their services to the people. These elements are also compatible with the demands of development that should be of necessity to shift in emphasis from the individual to the community as an organic whole.

Indeed, core values of African societies are found in the extended family system, shared concern for the vulnerable, collective actions in farming and building, among others. Through these practices founded in their culture, they were able to confront and overcome crises and conflicts that arouse in the course of development. Social structures such as families, lineages, clans, and ethno-religious groups remain strong, social units, which could well fill in the gap created by the absence of organized social welfare schemes by government. If such structures are carefully managed, they could play fundamental roles in seeking to realize the goal of collective wellbeing of the people, which is one of the core democratic values.

Thus, it is widely assumed that good democratic governance fosters transparency, accountability, the rule of law and constitutionalism, respect for civil and political rights, 
among others. All these values are necessary for securing economic prosperity, equitable distribution of resources and state legitimacy (Diamond, 1999). However, since the 80s when Africa first embraced the "Third Wave of Democratization" democracy remains largely unconsolidated in Africa (Huntington, 1991). This is demonstrated in widely disputed election results, excruciating poverty, rising insecurity, political instability, religious fanaticism, etc. Thus, the paper is to examine the intellectual "cobweb" as well as the interface between culture, democracy and good governance with the view of finding the missing link in Nigeria.

In the light of these developments, the paper examined the imperative of drawing from Nigeria's cherished cultural values to produce the much needed democratic consolidation, good governance and development in Africa. To realize these objectives, the paper is structured into the following sections: The first section chronicled introduction and objectives of the paper. The second section examined conceptual and theoretical issues central to the discourse. The third discussed the nature of Africa's cultural values as played out in the pre-colonial and colonial dispensations. The fourth analyzed the interface between traditional cultural values and the search for democracy, good governance and development in Africa. The fifth discussed some challenges which might inhibit the integration of indigenous cultural values into democratic and development practices in the continent. The sixth proffer the way forward in the context of the challenges identified; and then concluding remarks.

\section{Conceptual and Theoretical Underpinnings}

Some concepts in social and management sciences do not easily lend themselves to universally agreed definitions. This makes every definition perhaps only relevant within the parameters set for a given investigation. Culture belongs to the category often described as disputed concepts in social sciences where no universal meaning could be attached. The word culture was originally conceptualized as a tool for describing differences and similarities between groups of people. This is why it is described generally as the way of life of a people. In specific terms, culture could be refers to as configuration of learned and shared patterns of behaviour and understanding concerning the meaning and values of things, ideas, emotions, and actions (Odetola \& Ademola, 1990:38). In this view of culture, what comes out boldly to the fore is the point that 
culture is learned and shared ways of behaviours and understanding different kinds of things that man encounters in life.

This definition of culture resonates in other concepts. For example, culture is said "to relate to the beliefs and values people have about societies, social change and the ideal society they seek" (Billington et al, 1991). While there are different levels and definition of culture, many anthropologists and sociologists have tend to accept the definition of culture propounded by Sir Edward Taylor which conceptualized culture as that complex whole which includes; knowledge; belief; moral; law; customs and any other capabilities and habits acquired by man as a member of society (in Nnatu, 2002:51).The end point emphasizes the idea of culture as "a way of life." In particular, we are much interested in a culture where the natural end of man is his virtue and the wellbeing in community (Billington et al, 1991). Even democracy is affected by culture in the area of guaranteeing access of all individuals to its necessary and civilizing influence. This civilizing process, Mannheim argues is "ideally part of democratization that avails men the chance to broaden their abilities to participate and contribute to democratic governance" (in Billington et al, 1991).

Democracy following the Lincolnian approach is regarded as government of the people, by the people and for the people. While there are different perspectives to this concept, Moroeto Bobbio admonishes that:

However, much is reiterated that democracy is a term with many meanings which one can interpret in his own fashion, it does have one predominant meaning fully accepted by all those who invoke democracy and who are concerned with realizing socialism through it, so that once realized, socialism governs democratically (in Onyeoziri, 1988).

Thus, democracy is a cluster of rules permitting the broadest and surest direct and indirect participation of the majority of citizens in political decisions that is, in decision affecting the whole collectively. No country has been able to achieve complete democratic system as stated above. This explains why Dahl (in Akhakpe, 2014:39) came up with what he calls "Polyarchy." Polyarchies according to Dahl are "administrations that have been substantially popularized and liberalized, that is highly inclusive and extensively open to public contestation." The process of making polyarchies more democratic is referred to as democratization. 
Garreton (1995) sees democratization as the process of establishing, strengthening; extending the principles, mechanisms and institutions that defines a democratic administration. Democratization involves a political system embracing mere political openings, the rule of law and constitutionalism in spheres of the political system. Democracy was conceived in pre-colonial Africa, as rules, laws, and traditions, sometimes called customs that established how the people would live together peacefully as part of larger group while currently democracy is perceived as a system of government by the whole population or all the eligible members of a state, typically through elected representatives.

A related concept to democracy is governance. The concept 'governance' cannot be pinned down to a universally acceptable definition. This is because it has fallen into semantic predicament to the extent that the literature on it replete with so many definitions of the term by various scholars with different variant and subtype. However, we shall comb the conceptual terrain of the term with a view to finding the middle ground for its heuristic investigation. According to the United Nations Development Programme (UNDP, 2001) governance is defined as "the exercise of economic, political and administrative authorities to manage a country's affairs at all levels". Similarly, the World Governance Survey Report conceptualized governance as "the formulation and stewardship of the formal and informal rules that regulates the public realm, the arena in which state as well as economic and social actors interacts to make decisions (in Hyden and Court, 2002).

Recently the terms "governance" and "good governance" are being increasingly used in development literature. Bad governance is being increasingly regarded as one of the root of all evils within our societies. Major donors and international financial institutions are increasingly basing their aid and loans on the condition that reforms that ensure "good governance" are undertaken. Good governance has some characteristics, which include: It is participatory, consensus oriented, accountable, transparent, responsive, effective and efficient, equitable and inclusive and follows the rule of law. It assures that corruption is minimized, the views of minorities are taken into account and that the voices of the most vulnerable in society are heard in decision-making. It is also responsive to the present and future needs of society. Downer (2000) spells out political and economic principles for good governance. 
Politically, good governance entails the establishment of a representative and accountable form of government; Good governance requires a strong and pluralistic civil society, where there is freedom of expression and association; Good governance requires good institutions - sets of rules governing the actions of individuals and organizations and the negotiation of differences between them; Good governance requires the primacy of the rule of law, maintained through an impartial and effective legal system; and Good governance requires a high degree of transparency and accountability in public and corporate processes. A participatory approach to service delivery is important for public services to be effective.

Economically, good governance requires policies to promote broad-based economic growth, a dynamic private sector and social policies that will lead to poverty reduction. Economic growth is best achieved in an efficient, open, market-based economy.

Investment in people is a high priority, through policies and institutions that improve access to quality education, health and other services that underpin a country's human resource base. Effective institutions and good corporate governance are needed to support the development of a competitive private sector. In particular, for markets to function, social norms are needed that respect contract and property rights.

Yet, careful management of the national economy is vital in order to maximize economic and social advancement. Governance is the exercise of power or authority political, economic, administrative or otherwise - to manage a country's resources and affairs. It comprises the mechanisms, processes and institutions, through which citizens and groups articulate their interests, exercise their legal rights, meet their obligations and mediate their differences. Good governance means competent management of a country's resources and affairs in a manner that is open, transparent, accountable, equitable and responsive to people's needs. All these factors combined determine the level of development in a given society.

This brings us to the vexed issues of development. The term has endured conceptual and methodological shift over the years. In the 70s, development was associated with issues of growth in the economy, rise in per capita income and increase in Gross Domestic Product (GDP). However, Todaro (1982:16) provides a parameter for interrogating the issues of development. For him, objectives of development should include: ability to meet basic needs such as food, shelter, health and protection, achievement of self-esteem and human freedom. Todaro went further to argue that 
society deserves human freedom in form of emancipation from alienating material conditions of life and freedom from the social servitude of man and ignorance of nature, misery, institutional and dogmatic beliefs. Corroborating this view is Eberlee (2001) when he argued that in contemporary times, the concept of development has moved away from the fetishism of growth and development to the ability of a people to recover their resources and use same according to its cultural values to solve their individual and collective problems to bring about new frame of life where each stage is an improvement on the preceding one. What is at stake in Africa is development of man's wellbeing in the community. The re-invention of the people's cultural values is central to the sustainability of democracy and development particularly in ways they can impact on the people positively.

The subject matter of the paper could be predicated on several theoretical platforms, especially in the social and management sciences where perspectives often differ based on a scholar's orientation and worldview. These include political culture, elite, political participation, the two publics and the nature of society theories. While other theories may be relevant in their right, we anchor the paper on the nature of society theory to politics. Politics is grounded in the nature of society in which it takes place.

Dudley (in Akhakpe, 2014:44) made one of the elaborate attempts at explaining the political behavioural and institutional patterns of societies in terms of Weberian postulations on individuals and collective values embedded in their culture. The central thrust of Dudley's perspective is on the impact of the country - wide premium placed on wealth and status on politics. In Nigeria for example, there is the use of political office to enrich one's self. This is not seen however as corruption in as much, as the person involved is seen as contributing such ill-gotten wealth to the welfare and development of his community (Osaghae, 1988).

In addition, Osaghae (1994) stresses that the material perception of the state has made the political elite to seek for power mainly to enrich themselves and members of their groups. The reason why people seek power is not to further the ends of the people and community but that of self. This emergent political culture is negative because it promotes waste, poverty, political instability, insecurity and violence. In addition, it runs against the grain of African traditional cultural values of services, security and development of individuals and the community. To these virtues, we should return, for democracy and development to be sustained in the country. 


\section{The Nature of African Traditional Socio-Political Culture}

Africa presents medley of culture that it makes difficult to find an overarching generalization on one particular culture to recommend as basis of theoretical discourse. The pluralistic nature of the people culture makes such adventure cumbersome. Yet, such differentiations of cultural values are the hallmark of a heterogeneous society like Africa but they could be harvested to create robust and vibrant politico-social and economic systems. There are positive aspects of the different African culture that inform the core values of its societies.

The foundations of African traditional values are humanistic and communitarian. Africans place great emphasis on community, human welfare, and on what philosophers describe as "personhood." Communitarianism fosters a strong sense of community and a spirit of collectiveness. It emphasizes the relationality of individuals--- the fact that individuals are interdependent and subscribe to the same communal values. The notion that individuals must always seek communal, rather than individual good encourages people to be each other's keeper.

Communitarianism is what also informs the custom of holding land in trust for future generations rather than for individuals. The spirit of communality seeks the welfare of other less privileged members of society, and requires that well-to-do family members provide for and uplift poorer members of the family. Yet, Communitarianism see the community as a fundamental human good in an interdependent world, it constantly stresses harmony and co-operation and recognizes that actions of individuals affect the community as a whole. This does not mean that the individual was considered unimportant. Indeed African morality promotes the well-being of individuals and emphasizes that attributes of a person are those things that bring about dignity, respect, contentment, prosperity and joy to the individual and the community. But the communal being does not live in isolation; he is embedded in society.

A communal being therefore, naturally relates to others and is constituted, to an appreciable extent, by social relationships. The notion of "personhood," which is defined as moral achievement, explains the importance Africans attach to certain "humanistic" values. Personhood is attained in proportion to how one lives his life, and how one participates and discharges duties to the community. When an individual's conduct is consistently cruel, selfish and ungenerous, that individual is described as "not a person" 
(Gyekye, 1997). On the other hand, a person is that individual who has good character, generous, considerate, respectful to others, etc. Thus, being considered a person is a moral judgment that is based on assumptions that there are certain basic norms and ideals to which the individual should conform in order to be regarded as a patriotic citizen.

\section{linking Africa's Traditional Political Culture with Liberal Democracy: An Overview}

The mal-integration of Western political culture with Africa's traditional and political values has been at the heart of the debate for sustainable democracy in Africa. The emergent political institution and structure in Africa have failed after several years of experimentation to bring about stable socio-economic and political order in the continent (Ekeh, 1981).

At independence, expectations were high that the new Western administrative and political systems would contain and represent the diverse group interest of the body polity and resolve the different claims by groups and individual to power by appropriate alliance between political parties or compromise between parties (Basil, 1993). Western political system particularly liberal democracy, with its emphasis on individuals who are carriers of human rights is said to be "at variance with the group structure of socioeconomic organization and rights in Africa" (Osaghae, 1999).

This lack of synergy between these two processes and institutions made Arthur Lewis (in Joseph, 1989) to argues that "political system based on majority rule in which the victorious party directs the government and the unsuccessful one opposes, violates the fundamental rule of full participation for all". He went on to submit that plural societies cannot function peaceably if politics is regarded as a zero - sum - game, which functions according to the erroneous definition ---- that the majority is entitled to rule over the majority" (Joseph, 1989).

It is in view of the divisive nature of Western liberal democratic system that African's variant of socialism has been propounded and experimented in some states in the continent albeit with mixed results. The central element of this perspective according to Busia is that: 
One way of looking at Africa socialism is to see it as a search for effective methods for creating a new order built on the best traditions of the old, especially on the traditional sense of community and of solidarity between the individual and the group whereby the welfare of each member was bound up with the welfare of the whole community (in Osaghae, 1989).

This system of sharing with one another and working for the welfare and wellbeing of same formed the bases of stability and development in the pre-colonial order. But several forces that have unearthed the divisive tendencies among the African peoples such as have since overtaken this system: ethnicity, class, religion, etc. While these elements of traditional African political culture have been with the people through ages, they were never politicized or instrumentalized to cause disorder.

Indeed the core values of Africa society, including the extended family system, shared concern for the vulnerable, etc. have sustained Africa through decades of crisis, and could serve as the cultural foundation for future development. Some critics have perceived the extended family system as a burden on the more ambitious and hardworking individuals who are pressured to support their un-achieving relatives. Yet, Africa's social structures such as families, lineages, clans or even ethnicities, remain strong social units, and compensate for the absence of organized social welfare schemes. If such structures are carefully managed, they could play a key role in seeking the collective well being, as these have done for South East Asians and Indians.

Furthermore, the communitarian character of Africa society serves the purpose of democracy, if political power is decentralized and attention paid to the formation of town and district councils with mayors. That will ensure the participation of the local people in the decision making process, as is currently witnessed in Imo state, South East Nigeria. Such local assemblies, if open to all, will foster indigenous ideas of free expression, popular will, consensus and consultation, and help integrate in the modern system, the traditional intolerance of misrule and abuse of power. It helps facilitate communication between representatives and constituents as prevailed in traditional society, and alerts the governing executive to see the concerns and discontent, for which remedies may be sought for, to avert crisis and instability. The "Freedom Square" in Owerri where citizens and residents of the state can now go and express their views 
(positive or negative) without molestation, intimidations or fear of arrest is a typical example. The colonial system created a distance between the rulers and ruled. This system had no such early warning mechanism. In the words of Adedeji (1982), "Selfreliance can only be fostered in an environment that promotes the democratization of the development process, i.e. the active participation of the people in the development process."

It therefore logically follows, that some form of adaptation or transformation should be carried out in order to mitigate, if not eradicate, the divisive tendencies that characterized the practice of Western liberal democracy in areas like Africa. Nonetheless, such endeavour will throw up its own challenges, which should carefully be analyzed and addressed. In the section that follows, we identify some of these challenges.

\section{Challenges Facing the Linking of the Pre-Colonial Political Culture with the Present}

Africa has not progressed without some attempts to manage the forces of change that attended the incursion of Western culture into the continent. Attempt to find a middle ground in terms of structure, institution and behavioural pattern between the indigenous social structures that underwent changes and the "migrated social structures" that came with colonial rule brought about "emergent social structures" (Ekeh, 1989:95). Osaghae (1989) argues, these "were neither indigenous nor migrated, but emerged to meet societal needs which indigenous social structures and the migrated social structures could not fulfil in the colonial environment, like "tribalism" and ethnicity."

In all intents and purposes, these emergent social structures have been neither efficient nor effective in addressing problems, which emerged in the postcolonial dispensation. This is partly due to the use to which they were put. This use was certainly not to serve the common good, but parochial interests. This attitude and behaviour of the ruling elite is what Joseph (1987) describe as Prebendalism, that is, "patterns of political behaviour which rest on the justifying principles that such offices should be competed for and then utilized for personal benefit of the office holder as well as of their reference or support groups."

Working in tandem with the emergent social structures and institutions is the materialist perception of the state by political office seekers and holders. This materialist 
perception makes the primary objective of seeking state offices that of amassing material gains rather than serves the commonwealth. This was never the main motive of seeking power in the pre-colonial Africa. The competitive liberal democratic system makes this type of politics a winner takes all enterprise that is against the sharing philosophy of the communal Africa traditions.

Lack of respect for rules and regulations both written and unwritten, is a major impediment to stable democratic rule in Africa. Institutional rules are what sustain and bring about change in the society. In Western political system, apart from codified laws and conventions, there are unwritten rules of the game which limit the exercise of state powers. In Africa, constitutional provisions are flaunted at will while political contestants follow the path of war rather than apply institutional means to resolving conflicts.

There are also external challenges arising from attempts by the Western countries to impose their ideology on the rest of the world. They believe they have a manifest destiny to civilize the world through their own ideas, religion and politics etc. Most Africa people have resisted such cultural imperialism. But there are those who for selfish reasons would want to serve as cronies and stooges of Western ideological crusade through: globalization, modernization and various security arrangements with Africa State.

African leaders and people have not been able to effectively deal with these forces partly due to the parlous state of their economy that is made so by the exploitative capitalist system and the integration of Africa's economy into the unjust and oppressive economic order where the continent's economy plays second fiddle. All attempts by African states to wrangle out of this quagmire are effectively blocked by the massive infrastructure of economic domination from the West.

In addition, part of the difficulties African states experience is borne out of the greed of the political elite who prefer to follow Western precepts and examples insofar as they will enable them gain-privileged positions in the scheme of things in their countries than liberate their people from ignorance; hunger, poverty and underdevelopment. In this circumstance they find or use in transforming the system in order not to bring them into collusion with their benefactors in the West.

Members of the society in much of Africa have come to see the existing socioeconomic and political order as a "fait accomplish". Increasingly they are being convinced that the existing order is the best for them. In addition, as they are more 
westernized, it is believed that they are modernized. However, failure of socio-Western country's economic and political policies has started surfacing with riots and protest in the European major cities. Crises in these economies are indication that Western liberal economic system is not the only system that can work or bring about development.

\section{Culture, Democracy and Good Governance in Africa: Finding the Missing link}

The emphasis on humanity and personhood finds expression in several African maxims. A common name among the Igbos in Nigeria is "Madukaku," human being is worth more than wealth, "Nwanne Amaka" brotherhood is so precious and "Ezi Aha ka Ego" a good name is worth more than money (Igbokwe-Ibeto and Akhakpe, 2012:240). Another good example of the interface between culture, democracy and good governance can be found amongst the Igbos in Nigeria where culture of hard work is highly rated and determines one's status in the society. In "Chinua Achebe's Things Fall Apart," the importance of work is substantiated. The Yoruba culture also has something similar considering most of the wise saying, proverbs and Ifa liturgies (Igbokwe-Ibeto and Akhakpe, 2012:240). These are the principle and philosophies our founding fathers and Nationalist imbibed with, during the liberation struggle in Africa that made them achieved much in the governance and development of their respective countries despite the meagre resources at their disposal.

Regrettably, the culture of individualism and primitive accumulation of wealth have dislocated humanity and personhood in Africa. It is quite unfortunate and surprising that Africa is now in a sorry state of democracy and governance despite the huge human and material resources at her disposal waiting to be harvested, a situation which the World Bank has described as a paradox. The paradox is that the poverty level in Africa contradicts the continent's immense wealth. Rather than recording remarkable progress in socio-economic development, Africa retrogressed to among the continent with the poorest countries in the world.

\section{Culture, Democracy and Good Governance in Africa: The Way Forward}

In Africa, efforts directed at redirecting the ship of state in the positive direction so far appears to have failed. This calls for re-strategizing even by using the same method(s). 
The first port of call in this regard is to demand for re-orientation of leadership in all facets of societal life. The deficit in positive leadership has been so glaring that it finds expression in the decay in all aspects of life in Africa. Yet, no nation aspires to greatness without a critical mass of men and women of integrity, zeal and enthusiasm for their nation. The sooner Africa throws up this crop of leaders the quicker the continent's dream of greatness could be realized.

It is only when positive leadership is in place that socio-economic crisis of a country can be tackled and resolved. Economic crisis is an inevitable outcome of the capitalist model of organizing any economy. Nevertheless, it is not immutable, only if the African leaders can discipline themselves and cut down on wasteful spending. If a country like Nigeria could persecute its civil war without borrowing, in peacetime it can do better. Yet, no system can enjoy stability without economic growth and development. This is not to make a case for the modernization "ripeness" argument but to affirm that economic stability create room for peace and order in the polity.

The citizenry on their part should demonstrate more patriotism in dealing with issues that affect the nation. They should build more confidence in the country rather than be despondent and critical of its prospects. They should see themselves more in terms of duties and obligations to their country than what they can get from the state as units. Going back to the past, will be a fundamental step to ensuring stability and sustenance of democracy in Africa. One significant aspect of the pre-colonial political system that could be relevant to the present dispensation is the group solidarity basis of the state in Africa. This draws similarities with the social contract theories but with important variation. Awogu (in Osaghae, 1989) put it graphically:

The common link between social contract and Africa concept .... The difference was on degree, in African societies, there was near total surrender of rights for obligation, in Europe, John Locke and Jean Rousseau took the opposite view while Thomas Hobbes was closer to the African viewpoint.

Such a change in community - state relations in Africa present a brighter prospect for confronting the developmental challenges in the continent in general. However, one disturbing aspect of this relationship is that the states in Africa sometimes prevent 
groups or individuals from embarking on self-help projects by either invoking state laws against such efforts or physically resisting such attempts in the public place.

Poverty in the Africa presents yet the biggest obstacle to the realization of democracy and development in Africa. It is difficult to preach ethics or morality to a hungry man. The gap between the rich and poor is growing far apart daily and where there is preponderance of rich and poor people; such society is consistently prone to crisis and lawlessness. Therefore, poverty is a principal if not the principle obstacle to democracy and human development. Samuel Huntington (1991) makes this point vividly when he avers that: "Poverty is a principal - probably the principal obstacle to democratic development. The future of democracy depends on the future of economic development. Obstacles to economic development are obstacles to expansion of democracy."

However, beyond waiting for the state to provide the where with all for the people's empowerment, they can help themselves by organizing for production, distribution and other self-help activities as they have always done except that this time in greater and better dimensions using best practices from all over the world as the Asian Tigers have done drawing from their cultural values to change the present and future state of being.

It is significant that the state apparatus of most nation states in Africa includes various cultural motifs and symbolism that capture national ideals and virtues. These may depict various fauna and objects, whose features and traits best exemplify a desired quality (Makoba, 2004:545). Although maxims and visual symbolism in them do not ensure praxis, they are mementoes of cultural ideals that have shaped national fortunes. The state staff used in Ghana's parliament to announce the Speaker and his entourage, demonstrates Ghana's commitment to pristine cultural values at the founding of the nation state. The eagle symbolism portrays the features of grace, vigilance, and farsightedness for which the bird is known, and thus advocates same for the Speaker and the legislature.

Similarly, one could advocate a careful adoption of cultural symbolism within the state apparatus to reinforce good governance and democracy. The relevant motifs may be based on already existing maxims and cultural symbols that have guided good governance in traditional African society. We have in mind visual symbols of a hand holding an egg; two heads; and the beaks of two birds touching at the tip. The relevant messages: Good governance is like holding a fragile egg, two heads are better than one; 
and when two mouths meet, crisis is averted, are constant reminders of fundamental ingredients of good governance - judicious exercise of power, consultation, and consensus building (Makoba, 2004:544).

\section{Conclusion}

The paper interrogated the unending search for good governance and democratic consolidation in Africa. It advocated for the return to those relevant values in the people's traditional political culture that were abandoned due to the colonial interregnum. These among others include: group solidarity, high moral order in governance, community and state relations based on duties and obligations of the people to the state rather emphasis on rights, deep sense of hard work and self-reliant, even as they embrace best practices from outside the continent of Africa. With these and other steps if implemented will launch the continent on the path of democracy, good governance and development by retrieving and highlighting its uniqueness as a people with deep sense of history and pride.

Cultural values and institutions have proved highly resilient in spite of the onslaught of colonial and post-colonial impositions. Modernity has not succeeded in submerging the institution of chieftaincy and traditional rule in societies in East, West, North and South Africa. Clearly, the undergirding values of chieftaincy have not only survived, but have occasionally helped to consolidate and shape the fortunes of modern democratic systems. Thus, even modern African liberal democratic constitutions have made provisions for non-elective second chambers; modern elected presidents have adopted some of the trappings of traditional rulers in the area of mass communication and oath taking.

A critical evaluation of African cultural values and governance has shown that aspects of chieftaincy and traditional governance, coupled with some principal indigenous values are very much in accord with the basic tenets of modern democratic governance. Traditional political systems are often all-inclusive and accommodate civil society. In addition, the chief, though largely hereditary, is not autocratic. The chief occupant of a chieftaincy stool regards himself as having a binding social contract with his subjects and legitimacy of the chief is secured by both sacred oaths and performance. 


\section{List of References}

- Adedeji, A. 1982, "Development and Economic Growth in Africa to the Year 2000: Alternative Projections and Policies," in Timothy M. S. (Ed.), Alternative Futures in Africa, Boulder: Westview Press

- $\quad$ Akhakpe, I.P. 2014, Bureaucracy and Good Governance, Lagos: Pumark Nigeria Limited

- Basil, D. 1993, The Black Man's Burden: Africa and the Curse of the Nation - States, Ibadan: Spectrum books

- Billington et al, R. 1991, Culture and Society: A Sociology of Culture (Eds.),Macmillan Press Ltd, London

- Diamond, L. 1999, Developing Democracy towards Consolidation, Baltimore: The John Hopkins University Press

- Downer, A. 2000, Good Governance: Guiding Principles for Implementation. Canberra: AusAID.

- Eberlee, J. (2001), "Enhancing the role of traditional leaders in African governance," IDRC Report

- Ekeh, P 1975, "Colonialism and the Two Publics in Africa" Comparative Studies in History and Society, 17(1):91-112.

- $\quad$ Ekeh, P. 1989, "Colonialism and Social Structure in Africa", An Inaugural Lecture. University of Ibadan, Ibadan

- Gyekye, K. 1997, Tradition and Modernity, New York and Oxford: Oxford University Press

- Huntington, S.P. 1991, "Democracy's Third Ware" Journal of Democracy Spring

- Hyden, G \& Court, J, 2002 "Comparing Governance Across Countries and Times: Conceptual

- Hyden, G. 1980, Beyond Ujamaa in Tanzania: Underdevelopment and an Uncaptured Imperial Policy, London: Sweet and Maxwell Limited

- Igbokwe-Ibeto, C.J \& Akhakpe, I. 2012,"Culture, Democracy and Governance in Nigeria" in I.O Albert (Ed.), A History of Social Conflict and Conflict Management in Nigeria, Ibadan: Institute African studies, University of Ibadan, Ibadan: John Archers Publishers Ltd 
- Joseph, R. 1987, Democracy and Preberidal Politics in Nigeria: The Rise and fall of the Second Republic, Cambridge: University Press

- Makoba, W.J. 2004, "The Role of Africa's Culture in Economic Development", Journal of Modern African Studies, 30(4):543-568

- Mandani, M. 2002, Citizen and Subject: Contemporary Africa and the Legacy of Late Colonialism, Princeton: Princeton University Press

- Nnatu, S. 2002, "Culture" in N.G Egbue and A.C Edokobi (Eds.), Sociology: An Introduction, Enugu: Oktek Publishers

- Odetola,T.O \& Ademola, A. 1990, Sociology: An Introductory African Text, Low Cost Editions, London and Basingstoke: Macmillan Education LTD

- Onimode, B. 2007, "The Economic Basis of the National Question" in E. Osaghae and E. Onwudiwe (Eds.), The Management of the National Question in Nigeria, Okada: Igbinedion University Press

- Osaghae, E. 1988, The Crippled Giant: Nigeria Since Independence. Ibadan: John Achers Publishers

- Osaghae, E. 1989, "The Passage from the Past to the Present in African Political thought: The Question of Relevance" in J. Ayoade and A. Agbaje (Eds.), African Traditional Political Thought and Institutions, Lagos: Centre for Black and Africa Art and Civilization

- Osaghae, E. 1999, Democratization in Sub-Saharan Africa: Faltering Prospects of New Hopes for Peasantry, Berkeley: University of California Press

- Todaro, M.P. 1982, Economic Development in the World, New York: Longman Press

- United Nations Development Programme (UNDP) (2011). Nigerian Human Development Report 2000/2001 Millennium Edition, Lagos: UNDP.

\section{AUTHORS' CONTACT:}

IGBOKWE-IBETO C.J.

Dept of Public Administration

Nnamdi Azikiwe University

Awka, Nigeria

Email: ugochinyerecj@yahoo.co.uk
EWUIM Ngozi

Dept of Public Admin

Nnamdi Azikiwe Univ.

Awka, Nigeria
AGBODIKE Florence

Dept of Public Admin Nnamdi Azikiwe Univ. Awka, Nigeria 